\title{
Instrument Development for Socio-Educational Support and Socio-Educational Participation towards Educational Well-Being
}

\author{
Jalal Deen Careemdeen ${ }^{1,2}$ \\ Mohd Mahzan Awang' \\ Abdul Razaq Ahmad \\ Shakila Dahalan ${ }^{3}$ \\ ${ }^{1}$ Faculty of Education, The National University of Malaysia, \\ UKM, 4360o Bangi, Selangor, Malaysia \\ ${ }^{2}$ Faculty of Education, The Open University of Sri Lanka, \\ Nawala, Nugegoda 11222, Sri Lanka \\ ${ }^{3}$ Ministry of Education, Block E8, Parcel E, \\ Federal Government Administrative Centre, \\ 62604, 6200o Putrajaya, Malaysia
}

DOI: https://doi.org/10.36941/jesr-2021-0104

\section{Abstract}

The current study aims to develop and validate a questionnaire instrument to measure the socioenvironmental support, socio-educational participation and educational well-being indicators using Exploratory Factor Analysis (EFA) and Reliability Analysis among secondary school children in Sri Lanka. The indicators used in the analyses were based on sociological theories, and several past empirical studies identified to have three main constructs. The socio-environmental support construct which is based on Bronfenbrenner's (1989) ecological theory. The socio-educational participation construct which is developed in line with the Social Capital Theory (Putnam, 1993) and students' educational well-being construct, which was developed based on the Psychosocial Well-being Framework of Sri Lanka (2009). The pilot study was carried out, consisting of 50 secondary school children in Sri Lanka. The study results revealed that the value of Kaiser-Meyer-Olkin (KMO) test results for all constructs was above the cut-off level of 0.5. The Exploratory Factor Analysis of this study demonstrated that 35 items of socio-environmental support construct, 21 indicators of socio-educational participation construct, and 28 items of educational well-being construct were valid for measuring all those constructs. Reliability Analysis shows that each construct and indicators have good internal consistency values.

Keywords: Socio-Educational Support, Socio-Educational Participation, Educational Wellbeing, Confirmatory Factor Analysis, Reliability Analysis.

\section{Introduction}

Enhancing the quality of students' learning experience and student well-being are the main aims of the knowledge-based society to face the 21st-century challenges in the new millennium. The excellent 
learning environment and clear expectations will enhance student involvement in the learning process. A positive social environment improves students' motivation to learn, academic achievement, and cause the formation of students' behaviours and attitudes in several main areas, such as sensitivity, caring, decision-making, equality and justice. Socio-environmental factors have been found to play an essential role in student well-being (Casas et al., 2013; Pisa, 2015; Ratnik et al., 2017). Socio educational support in terms of teacher support, peer support, parental support, virtual support and community support for student learning tend to enhance students' learning, leading to student well-being (Careemdeen et al. 2020).

Further, the social capital theory in the educational circle focusing on educational participation in educational activities tends to enhance students' well-being (Ab Ghani et al. 2020; Cuc 2020). Social capital has an immense effect on student well-being. Putnam's social capital theory (1993) focusses on "features of social organization such as networks, norms, and social trust that facilitate coordination and cooperation for mutual benefit" (Putnam 1995, p. 67). Putnam (1993) states that social networks have value. Helliwell et al. (1999) have shown that there are far more educated people with social network strength than people with less knowledge. Social capital is produced through students' practice, such as participation and reciprocity. Huang (2009) discovered that student social capital, which is established by social relations with parents, teachers, and peers, has a major impact on student achievement. There is a positive relationship between social capital and student wellbeing (Buijs et al., 2016; Mcpherson et al., 2014; Yamaguchi, 2013).

On the other hand, inadequate support of the social environment complicates student life and causes problems. This is because environmental support affects a student's educational well-being and personality. Emotional changes such as low self-esteem, loneliness, and boredom can negatively impact student involvement in learning. As a result, students will be quiet, uncooperative, easily offended and demotivated (Chen et al. 2013). Low student well-being often leads to behavioural issues including college dropout, depression and suicidality (Renshaw et al. 2018).

\section{Instrument Development for Measuring Socio-Educational Support and Socio- Educational Participation towards Educational Wellbeing}

There has been growing interest in human well-being studies. It is still challenging to obtain comprehensive instrumentation related to socio-educational support and socio-educational participation in students' educational well-being among secondary school children. Past studies have also focused less on issues which affect students' educational well-being concerning socioenvironmental factors and socio-educational participation. Meanwhile, the instrumentation available outside Sri Lanka has measured socio-environmental support and student involvement for soft skills development among secondary school children in Malaysia (Sidik 2019), and social support and leisure activities for leisure well-being among youth (Hamid et al., 2020), but not measured students' educational well-being

The limited studies that have been conducted have focused on students' well-being related to socio-environmental support and socio-educational participation. The current study aims to develop and validate instruments for measuring socio-environmental support and socio-educational participation in the pursuit of educational well-being among secondary school children in Sri Lanka.

\section{Research Framework}

This study employs a research framework based on several sociological theories and the Psychosocial Well-being Framework of Sri Lanka (2009). There are three primary constructs in this framework. The first construct is socio-environmental support, which is based on Bronfenbrenner's (1979) socioecological theory, the second is socio-educational participation based on the Social Capital Theory (Putnam 1993), and the third is educational well-being based on the Psychosocial Well-being Framework of Sri Lanka (2009). 
The indicators for socio-environmental support constructs were developed based on Bronfenbrenner's (1979) socioecological theory, which emphasizes how the social context of individual interactions and experiences determines how individuals develop their abilities and realize their potentials. Moreover, several empirical studies which have also considered developing the instrument revealed that socio-environmental support has a positive relationship with student wellbeing. For instance, Nirmala et al. (2018) found that help from parents, peers, and teachers leads to students' well-being. In accordance with Bronfenbrenner's (1979) socioecological theory and empirical studies, home environment, school environment, community environment and virtual environment were conceptualized as student educational environment to develop an instrument for socio-environment construct. In the home environment, parents play a significant role in educating children. According to Boonk et al. (2018), parents' high expectations/aspirations for the academic achievement and education of their children and education, parental motivation, and support for learning are all linked to academic achievement. On the other hand, Kiefer et al. (2015) highlighted that in the school environment, teacher and peer educational support may foster a responsive learning environment, and have unique implications for supporting adolescents' academic motivation, classroom engagement, and school belonging. Furthermore, in the community environment, community organizations contribute to the upgrading of school facilities, the improvement of school staffing and leadership, the organization of learning programs for students, the provision of new resources, the improvement of curriculum and teaching and the identification of funds for school programs (Henderson et al. 2002). Besides, the virtual environment influences student involvement in learning, in ways such that they tend to learn more school subjects, explore more new information, and seek out more on global and local issues (Köse 2016).

The indicators for socio-educational participation construct are based on the Social Capital Theory (Putnam, 1993). His theory focusses on 'features of social organization such as networks, norms, and social trust that facilitate coordination and cooperation for mutual benefit' (Putnam 1995, p. 67). Putnam (1993) states that social networks have value. He emphasized three forms of social networks that need to be strengthened: social capital bonding, bridging social capital and linking social capital. Bonding social capital means trusting and cooperative relations among members of a network who see themselves as sharing an identity. Social capital needs the collaboration of other participants and takes a period to develop through exchanges and interaction (Nahapiet et al. 1998). Education generates social capital in three basic ways: First of all, students practise skills in social capital, like participation and reciprocity. Secondly, schools provide community activities forums. Third, students learn how to take a responsible part in their society through civic education (Helliwell \& Putnam, 1999). Based on the Social capital theory and empirical studies, socioeducational participation constructs are divided into three components: (1) parental participation in student learning, (2) student participation in lesson activities and (3) student participation in school activities. Parental participation was found to be related to more school self-esteem and higher academic competence and higher grade scores (Dotterer et al. 2016). Students' active classroom participation supports student learning, push them to be more motivated, promotes higher-order thinking skills and improves their communication skills (Aziz et al., 2018). Level of student participation in education is linked to socio-environmental support (Aziz et al. 2018; Ghalley et al., 2019; Saleha 2015), and active students' involvement in learning is the main aspect that influences the students' academic attainment (Park 2005; Singh et al., 2015). Students who participated in extracurricular activities, such as sports or school club or music programs had scored higher point averages than students who did not participate in those activities (Craft 2012). Finn (1989) claims that students feel a sense of belonging and identity when they participate in school activities, which helps them become resilient learners and encourages a sense of self-worth, particularly if they are at risk of dropping out before completing their secondary education. Students who engaged in more extracurricular activities as lengthier amounts of time showed more excellent adjustment indicators (Metsäpelto \& Pulkkinen, 2012). Student participation in lesson activities (Ing et al., 2015), extracurricular activities (Freeman 2017; Sidik et al., 2019) and parental participation in student 
learning have all been positively associated with student educational achievement (Aliyu 2018).

The indicators for students' educational well-being construct are based on the Psychosocial Well-being Framework of Sri Lanka (2009). According to the framework, an individual (or family or community) experiences well-being when they can: access physical, material, and intellectual resources; experience competence and self-worth; exercise participation; build social connections; and enhance physical and psychological wellness (Abeyasekera et al. 2008). This framework has been focused on the equity of a social justice approach, especially regarding the distribution of resources, whether in terms of material, social or cultural (Abeyasekera et al. 2008). Based on the Psychosocial Well-being Framework of Sri Lanka (2009) and empirical studies, students' educational well-being constructs are divided into four components: (1) access to educational resources, (2) hard skills (3) soft skills, and (4) social skills functioning and capabilities that students need to live a happy and fulfilling life. Student well-being is a researchable construct. Many studies have identified factors that impact student well-being, including social support, socio-educational participation, religion, gender, income, and socio-economic background. When the concept of social support appeared in the literature, the studies on the relationship between well-being and social support were the most common (Sheldon, et al 1985). Cohen and Wills (1985) state that social support brings significance contributions to one's well-being. Several empirical studies highlighted that there is a strong relationship between social support and student well-being. Estonian students showed a higher level of well-being as they have good relationship with their parents, teachers, peers, and have a broader communication culture in school (Ratnik et al. 2017).

\section{Objectives of the Study}

This current study aims to develop and validate questionnaire instruments for measuring socioenvironmental support and socio-educational participation towards educational well-being. Significantly, this study aims to find out the most appropriate indicators and internal consistency for each item in the questionnaire to measure socio-environmental support, socio-educational participation towards educational well-being among secondary school children.

\section{Methodology}

This study employed a survey research design based on a small scale focusing on developing and validating instruments for determining socio-environmental support and socio-educational participation in students' educational well-being. There are four main stages to carry on this research:

\subsection{Stage 1: Developing a Conceptual Framework}

The conceptual framework of this study was developed based on Bronfenbrenner's (1989) ecological theory, Putnam's (1993) Social Capital Theory of (Putnam, 1993) and the Psychosocial Wellbeing Framework of Sri Lanka (2009). Socio-environmental support in this study, which is based on Bronfenbrenner's (1989) ecological theory emphasises four kinds of socio-educational support: (1) home environmental support, (2) school environmental support, (3) community environmental support, and (4) virtual ecological support. Socio-educational participation based on the Social Capital Theory of Putnam (1993) emphasises three kinds of socio-educational participation: (1) parental involvement in student learning, (2) student participation in lesson activities and (3) student participation in school activities. Educational well-being, which is in line with the Psychosocial Wellbeing Framework of Sri Lanka (2009), emphasises four kinds of well-being: (1) access to educational resources, (2) soft skills, (3) social skills and (4) hard skills functioning and capabilities that students need to live a happy and fulfilling life. Accordingly, the conceptual framework has been used to develop the questionnaire. 


\subsection{Stage 2: Designing and Validating the Instrument}

Stage 2 was the development of items and indicators based on the framework. The indicators were then reviewed by three educational and sociology experts. The instrument was improved independently based on the suggestions and comments by these three experts. In accordance with experts' comments, all the items of the instrument have been corrected. Moreover, all the indicators have been proofread by English language experts to ensure the accuracy of the language. To check the instrument face validity, ten students reviewed the revised instruments. Overall, the indicators in the tool are representative of each construct. The instrument employed a five-point Likert scale.

\subsection{Stage 3: Survey}

A small-scale survey was carried out involving 50 Sri Lankan secondary school children using a random sampling technique. The random approach is considered more appropriate for selecting a sample without bias judgement as there is an equal chance of selecting respondents. There are ongoing debates about the appropriate sample size for validating new instruments. However, Johansson and Brooks (2010) suggest that "thirty representative participants from the population of interest are a reasonable minimum recommendation for a pilot study where the purpose is a preliminary survey or scale development" (p. 399). On the other hand, Malhotra (2007) pointed out that to identify a new instrument's validity scores and reliability, 15-30 respondents are sufficient. In line with those recommendations, a total of 50 Sri Lankan secondary school students were selected at random for the present study. As this study aims to validate the indicators for assessing socioenvironmental support and socio-educational participation in educational well-being instrument, the outcomes of this stage are important to use for larger data collection. However, as the sample size is minimal, the results of this study cannot be used for generalization for the population.

\subsection{Stage 4: Data Analyses}

Data collected from the small-scale survey were analysed using Exploratory Factor Analysis and Reliability Analysis (Cronbach's Alpha) SPSS software.

\section{Results}

\subsection{Factor Analysis}

A factor analysis was performed to evaluate the indicators identified for assessing socioenvironmental and socio-educational participation in the student educational well-being instrument. Kaiser-Meyer-Olkin (KMO) and Bartlett's Test of Sphericity were carried out in order to analyse the valid items for each component. Exploratory Factor Analysis was tested using Kaiser-Meyer-Olkin (KMO) and Bartlett's Test of Sphericity. Reliability analysis was performed using the Statistical Package for the Social Sciences (SPSS) Version 23 to obtain Cronbach's Alpha for each indicator, component and constructs.

\subsection{Factor Analysis of Socio- Environment Support Construct}

As shown in Table 1, the test for KMO yielded a value of 0.626 . This value was higher than the 0.5 cutoff point, and as stated by Tabachnick and Fidell (2001), this indicated that the sample was adequate to test factor analysis.

As shown in Table 2, there are five components for assessing the socio-environmental support index. Results show that there are 35 items measuring the various components. This means that all 35 items and five components are valid for measuring the social-environmental support index. There are for five components of social-environmental support index based on the pattern Matrix. 
Table 1: KMO and Bartlett's Test for all items

\begin{tabular}{|l|c|c|}
\hline Kaiser-Meyer-Olkin Measure of Sampling Adequacy. & 0.626 \\
\hline \multirow{3}{*}{ Bartlett's Test of Sphericity } & Approx. Chi-Square & $2095 \cdot 775$ \\
\cline { 2 - 3 } & Df & 595 \\
\cline { 2 - 3 } & Sig. & 0.000 \\
\hline
\end{tabular}

Table 2: Pattern matrix for all items

\begin{tabular}{|c|c|c|c|c|c|}
\hline & & & Compon & & \\
\hline & $\mathrm{i}$ & ii & iii & iv & $\mathrm{v}$ \\
\hline B1.1 & & & & 0.586 & \\
\hline B1.2 & & & & 0.801 & \\
\hline B1.3 & & & & 0.936 & \\
\hline B1.4 & & & & 0.830 & \\
\hline B1.5 & & & & 0.901 & \\
\hline B1.6 & & & & 0.740 & \\
\hline $\mathrm{B} 1.7$ & & & & 0.813 & \\
\hline B2.1 & & 0.855 & & & \\
\hline B2.2 & & 0.845 & & & \\
\hline $\mathrm{B} 2.3$ & & 0.797 & & & \\
\hline $\mathrm{B} 2.4$ & & 0.714 & & & \\
\hline B2.5 & & 0.917 & & & \\
\hline $\mathrm{B} 2.6$ & & 0.820 & & & \\
\hline B2.7 & & 0.921 & & & \\
\hline B3.1 & & & 0.770 & & \\
\hline B3.2 & & & 0.730 & & \\
\hline B3.3 & & & 0.865 & & \\
\hline B3.4 & & & 0.904 & & \\
\hline B3.5 & & & 0.781 & & \\
\hline B3.6 & & & 0.873 & & \\
\hline B3.7 & & & 0.872 & & \\
\hline B4.1 & 0.781 & & & & \\
\hline B 4.2 & 0.719 & & & & \\
\hline B4.3 & 0.900 & & & & \\
\hline B4.4 & 0.942 & & & & \\
\hline B4.5 & 0.949 & & & & \\
\hline B4.6 & 0.888 & & & & \\
\hline B4.7 & 0.880 & & & & \\
\hline B5.1 & & & & & -0.834 \\
\hline $\mathrm{B}_{5.2}$ & & & & & -0.925 \\
\hline $\mathrm{B}_{5.3}$ & & & & & -0.940 \\
\hline B5.4 & & & & & -0.900 \\
\hline B5.5 & & & & & -0.918 \\
\hline B5.6 & & & & & -0.880 \\
\hline B5.7 & & & & & -0.881 \\
\hline $\begin{array}{l}\text { Extra } \\
\text { Rotat }\end{array}$ & $\begin{array}{l}\text { : Princ } \\
\text { Oblimi }\end{array}$ & $\begin{array}{l}\text { Onent } \\
\text { iser No }\end{array}$ & & & \\
\hline
\end{tabular}

The internal consistency values (Cronbach's Alpha) for these five components are 0.912, 0.953, 0.933, 0.971, and 0.981 and these values are considered good. Overall, the Cronbach Alpha value for socioenvironmental support is 0.951. These values are within an acceptable range (Cohen et al., 2017). 
Table 3: Reliability of Socio Environmental Support

\begin{tabular}{|c|l|c|c|}
\hline & Sub-Constructs & Cronbach's Alpha Value & \multirow{2}{*}{ Total Cronbach's Alpha } \\
\hline o1. & Parental Support & 0.912 & \multirow{2}{*}{0.951} \\
\hline 02. & Teacher Support & 0.953 & \multirow{2}{*}{} \\
\hline 03. & Peer Support & 0.933 & \\
\hline 04. & Community Support & 0.971 & \\
\hline 05. & Virtual Support & 0.981 & \\
\hline
\end{tabular}

\subsection{Social Educational Participation}

As shown in Table 4, the KMO test yielded a value of o.704. According to Tabachnick and Fidell (2001), this value was higher than the cut-off level of 0.5, indicating that the sample was large enough to evaluate factor analysis.

As shown in Table 5, there are three components for the purpose of assessing the socioeducational participation index. Results show that there are 21 items measuring the various components. This means that all 21 items and three constructs are valid for measuring the socioeducational participation index. There are three components of socio-educational participation index based on the pattern Matrix.

Table 4: KMO and Bartlett's Test for all items

\begin{tabular}{|l|c|c|}
\hline Kaiser-Meyer-Olkin Measure of Sampling Adequacy. & 0.704 \\
\hline \multirow{3}{*}{ Bartlett's Test of Sphericity } & Approx. Chi-Square & 741.857 \\
\cline { 2 - 3 } & Df & 210 \\
\cline { 2 - 3 } & Sig. & 0.000 \\
\hline
\end{tabular}

Table 5: Pattern matrix for all items

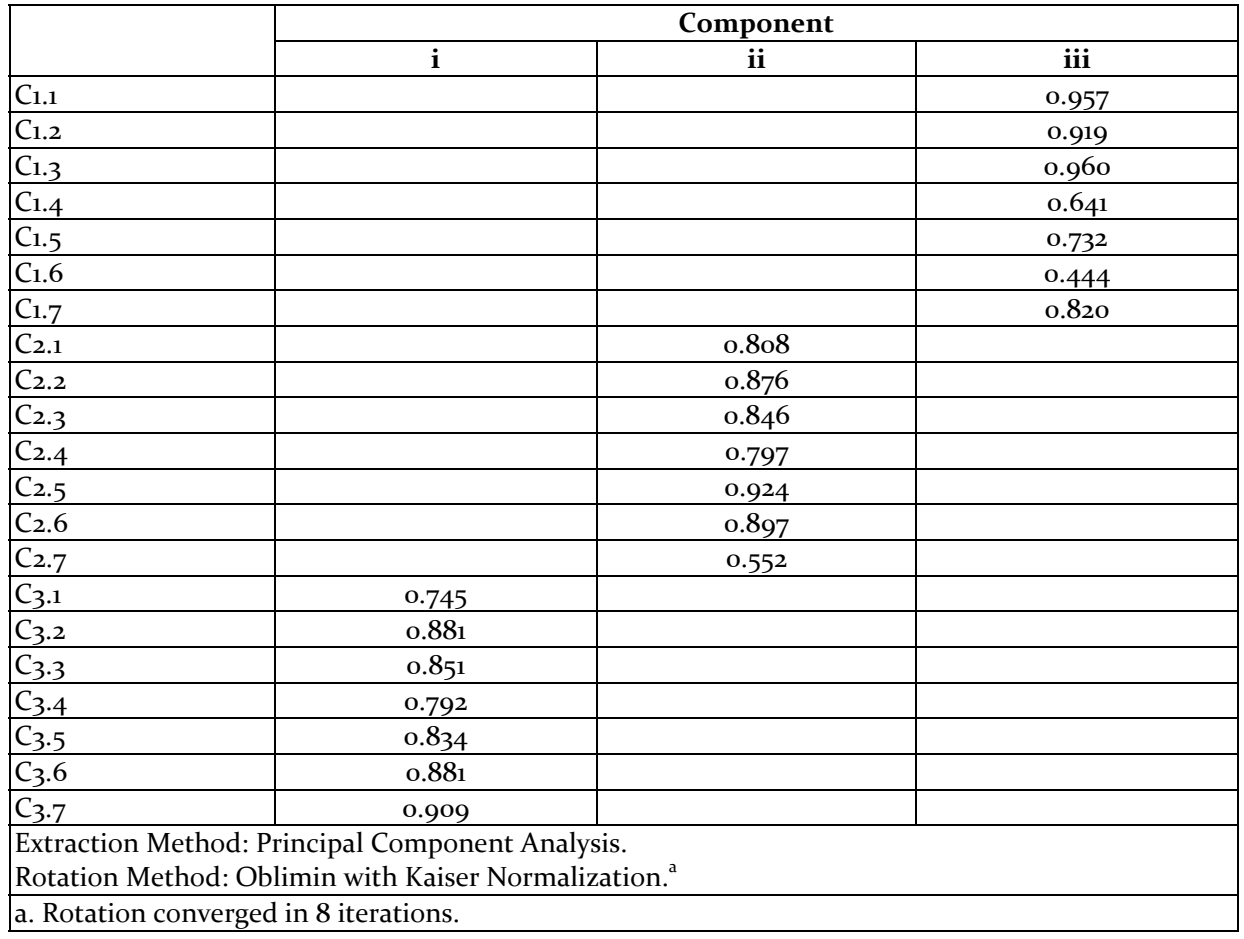


The internal consistency values (Cronbach's Alpha) for these three components are 0.913, 0.939 and 0.940 and these values are considered good. Overall, the Cronbach Alpha value for socio-educational participation is 0.936 These values are within an acceptable range (Cohen et al. 2017).

Table 6: Reliability of Socio Educational Participation

\begin{tabular}{|c|c|c|c|}
\hline No. & Socio Educational Participation & Alpha value & Over all Alpha value \\
\hline 01. & Parental Participation & 0.913 & \multirow{3}{*}{0.936} \\
\hline 02. & Student Participation in Lesson Activities & 0.939 & \\
\hline O3. & Student Participation in School Activities & 0.940 & \\
\hline
\end{tabular}

\subsection{Educational Well-Being}

As shown in Table 7, the KMO test yielded a value of 0.629 . According to Tabachnick and Fidell (2001), this value was higher than the cut-off level of 0.5 , indicating that the sample was sufficient to evaluate factor analysis.

As shown in Table 8, there are four components for the purpose of assessing the index of educational well-being. Results show that there are 28 items measuring the various components. This means that all 28 items and the four components are found to be valid for measuring the educational well-being index. There are for four components of educational well-being index based on the pattern Matrix.

Table 7: KMO and Bartlett's Test for all items

\begin{tabular}{|l|c|c|}
\hline Kaiser-Meyer-Olkin Measure of Sampling Adequacy. & 0.629 \\
\hline \multirow{3}{*}{ Bartlett's Test of Sphericity } & Approx. Chi-Square & 1017.572 \\
\cline { 2 - 3 } & Df & 378 \\
\cline { 2 - 3 } & Sig. & 0.000 \\
\hline
\end{tabular}

Table 8: Pattern matrix for all items

\begin{tabular}{|c|c|c|c|c|}
\hline & & & & \\
\hline & i & ii & iii & iv \\
\hline D1.1 & & -0.914 & & \\
\hline D1.2 & & -0.700 & & \\
\hline D1.3 & & -0.884 & & \\
\hline D1.4 & & -0.883 & & \\
\hline D1.5 & & -0.922 & & \\
\hline D1.6 & & -0.607 & & \\
\hline D1.7 & & -0.803 & & \\
\hline $\mathrm{D}_{2.1}$ & & & & 0.740 \\
\hline $\mathrm{D}_{2.2}$ & & & & 0.866 \\
\hline $\mathrm{D}_{2.3}$ & & & & 0.866 \\
\hline $\mathrm{D}_{2.4}$ & & & & 0.849 \\
\hline D2.5 & & & & 0.725 \\
\hline $\mathrm{D}_{2.6}$ & & & & 0.830 \\
\hline D2.7 & & & & 0.828 \\
\hline$D_{3.1}$ & & & -0.725 & \\
\hline $\mathrm{D}_{3.2}$ & & & -0.901 & \\
\hline$D_{3.3}$ & & & -0.896 & \\
\hline $\mathrm{D}_{3.4}$ & & & -0.783 & \\
\hline$D_{3.5}$ & & & -0.804 & \\
\hline
\end{tabular}




\begin{tabular}{|l|c|c|c|c|}
\hline \multirow{2}{*}{} & i & ii & iii & iv \\
\cline { 2 - 5 } & & & -0.803 & \\
\hline $\mathrm{D}_{3.6}$ & & & -0.861 & \\
\hline $\mathrm{D}_{3.7}$ & 0.842 & & & \\
\hline $\mathrm{D}_{4.1}$ & 0.900 & & & \\
\hline $\mathrm{D}_{4.2}$ & 0.956 & & & \\
\hline $\mathrm{D}_{4.3}$ & 0.797 & & & \\
\hline $\mathrm{D}_{4.4}$ & 0.866 & & & \\
\hline $\mathrm{D}_{4.5}$ & 0.874 & & & \\
\hline $\mathrm{D}_{4.6}$ & 0.790 & & & \\
\hline D4.7 & & & \\
\hline Extraction Method: Principal Component Analysis. \\
Rotation Method: Oblimin with Kaiser Normalization. ${ }^{\mathrm{a}}$ \\
\hline
\end{tabular}

The internal consistency values (Cronbach's Alpha) for these four components are 0.926, o.917, o.934 and o.945. Overall, the Cronbach Alpha value for socio-environmental support is 0.898 These values are within an acceptable range (Cohen et al. 2017).

Table 9: Reliability of Educational Well-Being

\begin{tabular}{|l|l|c|c|}
\hline No & Educational Wellbeing & Alpha value & Overall Alpha value \\
\hline o1. & Accsess to Resources & 0.926 & \multirow{2}{*}{0} \\
\hline o2. & Soft Skills & 0.917 & \multirow{2}{*}{0.898} \\
\hline o3. & Social Skills & 0.934 & \\
\hline 04. & Hard Skills & 0.945 & \\
\hline
\end{tabular}

\section{Discussion and Conclusion}

The results show that all indicators from all three constructs are valid and reliable for use. Moreover, results demonstrated that the KMO test resulted in a value of $0.626,0.704$, and 0.629 for socioenvironmental support construct, socio-educational participation constructs and educational wellbeing construct respectively. According to Tabachnick and Fidell (2001), all of these values were higher than the cut-off level of 0.5, suggesting that the sample was large enough to evaluate factor analysis. The Exploratory Factor Analysis revealed that 35 items of the socio-environmental support construct, 21 indicators of the socio-educational participations construct, and 28 items of the educational wellbeing construct are valid for measuring all those constructs.

Moreover, the results revealed that these three constructs, in terms of socio-environmental support, socio-educational participation and educational wellbeing each have overall good internal consistency values (Cronbach's Alpha) of 0.951, 0.936 and 0.898 respectively, while subconstructs and components of each constructs' internal consistency values (Cronbach's Alpha) have good internal consistency values. Accordingly, the reliability of the environmental support instrument shows in terms of parental support (o.912), teacher support (o.953), peer support (o.933), local community support (0.971) and virtual support (0.981) has a high Alpha value. Moreover, the reliability of the socio-educational participation instrument shows in terms of parental participation (o.913), student participation in lesson activities (0.939) and student participation in school activities (0.940) has a high Alpha value. Furthermore, the reliability of the educational wellbeing instrument shows in terms of access to educational resources (0.926), soft skills (0.917), social skills (0.934), and hard skills (o.945) has a high Alpha value. As reported by Nunnally J. C. \& Bernstein I. H. (1994) and Abu Bakar (1987), both of these values were higher than the correlation value of $r=0.3$, which is used to assess the validity of the item for measuring the construct. 


\section{References}

Ab Ghani, S., Awang, M. M., Ajit, G. \& Rani, M. a. M. (2020) Participation in Co-Curriculum Activities and Students' Leadership Skills. Journal of Southwest Jiaotong University. https://doi.org/10.35741/issn.0258$2724 \cdot 55 \cdot 4.48$

Abeyasekera, A., Amarasuriya, H. \& Ferdinando, M. (2008). Understanding Well-Being in Sri Lanka: A Psychosocial Framework. A tool, a guide and a framework 11-22. Social Policy Analysis and Research Centre (SPARC)Faculty of ArtsUniversity of Colombo

Aziz, F., Quraishi, U. \& Kazi, A. S. (2018). Factors Behind Classroom Participation of Secondary School Students (a Gender Based Analysis). Universal Journal of Educational Research 6(2): 211-217. DOI: 10.13189/ujer.2018.060201

Boonk, L., Gijselaers, H. J. M., Ritzen, H. \& Brand-Gruwel, S. (2018). A Review of the Relationship between Parental Involvement Indicators and Academic Achievement. Educational Research Review 24(10-30. https://doi.org/10.1016/j.edurev.2018.02.001

Bronfenbrenner, U. (1979). The Ecology of Human Development. Harvard university press.

Buijs, T., Maes, L., Salonna, F., Van Damme, J., Hublet, A., Kebza, V., Costongs, C., Currie, C. \& De Clercq, B. (2016). The Role of Community Social Capital in the Relationship between Socioeconomic Status and Adolescent Life Satisfaction: Mediating or Moderating? Evidence from Czech Data. International journal for equity in health 15(1): 203. https://equityhealthj.biomedcentral.com/articles/10.1186/s12939-016-0490-X

Careemdeen, J. D., Awang, M. M. \& Ahmad, A. R. (2020). A Grey Literature Review on the Impact of SocioEnvironmental Support and Socio-Educational Participation Towards Students' Wellbeing. International Journal of Psychosocial Rehabilitation 24(1):

DOI: $10.37200 / \mathrm{IJPR} / \mathrm{V}_{24} \mathrm{I}$ 1/PR200645

Casas, F., Bălţătescu, S., Bertran, I., González, M. \& Hatos, A. (2013). School Satisfaction among Adolescents: Testing Different Indicators for Its Measurement and Its Relationship with Overall Life Satisfaction and Subjective Well-Being in Romania and Spain. Social Indicators Research 111(3): 665-681. DOI 10.1007/s11205012-0025-9

Chen, T. S. \& Sutan, R. (2013). Faktor-Faktor Sokongan Sosial Yang Mempengaruhi Penghargaan Kendiri Remaja Sekolah Menengah Daerah Melaka Tengah (the Social Support Factor Influencing the Self Esteem of Adolescents within Secondary Schools in Mid Malacca District). e-Bangi 10(1): https://ejournal.ukm.my/ebangi/article/view/11193/3620

Cohen, L., Manion, L. \& Morrison, K. (2017). Research Methods in Education. routledge.

Craft, S. W. (2012). The Impact of Extracurricular Activities on Student Achievement at the High School Level. Steven Wesley Craft, University of Southern Mississippi

Cuc, P. G. (2020) The Role of Social Capital in Children's Development. Romanian Journal of School Psychology,13(25):48-54. https://search.proquest.com/openview/54ffd9402f31db43c92ae82e1od2d184/1?pqorigsite $=$ gscholar $\& \mathrm{cbl}=2050687$

Dotterer, A. M. \& Wehrspann, E. (2016). Parent Involvement and Academic Outcomes among Urban Adolescents: Examining the Role of School Engagement. Educational Psychology 36(4): 812-83o. https://doi.org/10.108o/ 01443410.2015.1099617

Finn, J. D. (1989.) Withdrawing from School. Review of educational research 59(2): $117-142$. https://doi.org/10.3102/o0346543059002117

Ghalley, L. R. \& Rai, B. M. (2019). Factors Influencing Classroom Participation: A Case Study of Bhutanese Higher Secondary Student. Asian Journal of Education and Social Studies 1-14.DOI: 10.9734/ajess/2019/v4i330118

Hamid, N. H., Awang, M. M. \& Ahmad, A. R. (2020). Instrument Development for Social Support and Leisure Activities Towards Well-Being among Youth. Solid State Technology 63(6): 3007-3021. http://solidstatetechnology.us/index.php/JSST/article/view/3385

Helliwell, J. F. \& Putnam, R. D. (1999). Education and Social Capital. National Bureau of Economic Research.

Henderson, A. T. \& Mapp, K. L. (2002). A New Wave of Evidence: The Impact of School, Family, and Community Connections on Student Achievement. Annual Synthesis, 2002. https://eric.ed.gov/?id=ED474521

Huang, L. (2009). Social Capital and Student Achievement in Norwegian Secondary Schools. Learning and Individual Differences 19(2): 320-325. https://doi.org/10.1016/j.lindif.2008.11.004

Kiefer, S. M., Alley, K. M. \& Ellerbrock, C. R. (2015) Teacher and Peer Support for Young Adolescents' Motivation, Engagement, and School Belonging. Rmle Online 38(8): 1-18. https://doi.org/10.108o/19404476.2015.11641184

Köse, U. (2016). Effects of Social Media on Students: An Evaluation Approach in Turkey. Dlm. (pnyt.). Social Networking and Education, hlm. 189-212. Springer. https://link.springer.com/chapter/10.1007/978-3-31917716-8_12 
Mcpherson, K. E., Kerr, S., Mcgee, E., Morgan, A., Cheater, F. M., Mclean, J. \& Egan, J. (2014) The Association between Social Capital and Mental Health and Behavioural Problems in Children and Adolescents: An Integrative Review. https://link.springer.com/article/10.1186/2050-7283-2-7

Nahapiet, J. \& Ghoshal, S. (1998). Social Capital, Intellectual Capital, and the Organizational Advantage. Academy of management review 23(2): 242-266. https://doi.org/10.5465/amr.1998.533225

Nirmala, A., Valarmathi, V., Venkataraman, P., Kanniammal, C. \& Arulappan, J. (2018). Factors Influencing the General Well Being of Adolescents with Health Problems. Available at SSRN 3204904 http://dx.doi.org/10.2139/ssrn.3204904

Nunnally J. C. \& Bernstein I. H. (1994). Psychometric Theory. New York: McGrawHill.

PADHI, (2009). Psychosocial Assessment of Development and Humanitarian Interventions Program. Understanding Well Being Sri Lanka. A tool a Guide and a Framework. Social Policy Analysis and Research Centre (SPARC)Faculty of ArtsUniversity of Colombo

Park, S.-Y. (2005). Student Engagement and Classroom Variables in Improving Mathematics Achievement. Asia Pacific Education Review 6(1): 87-97. https://link.springer.com/article/10.1007/BFo3024970

PISA. (2015). Results (Volume Iii): Students' Well-Being. Paris: Author; 2017.

Putnam, R. (1993.) The Prosperous Community: Social Capital and Public Life. The american prospect 13(Spring), Vol. 4. Available online: http://www. prospect. org/print/vol/13

Ratnik, M. \& Rüütel, E. (2017). School Factors Affecting Estonian Students' Subjective Well-Being at the Basic School. Problems of Education in the 21st Century 75(6): 599. http://www.scientiasocialis.lt/pec/node/files/pdf/vol75/599-611.Ratnik_Vol.75-6_PEC.pdf

Renshaw, T. L. \& Chenier, J. S. (2018). Further Validation of the Student Subjective Wellbeing Questionnaire: Comparing First-Order and Second-Order Factor Effects on Actual School Outcomes. Journal of Psychoeducational Assessment 36(4): 392-397. https://doi.org/10.1177/o734282916678494

Sidik, I. F. 2019. Sokongan Persekitaran Dan Keterlibatan Pelajar Dalam Meningkatkan Kemahiran Insaniah Di Pelbagai Sekolah Menengah Di Malaysia. Fakulti Pendidikan, Universiti Kebangsaan Malaysia.

Singh, A. K., Srivastava, S. \& Singh, D. 2015. Student Engagement as the Predictor of Direct and Indirect Learning Outcomes in the Management Education Context. Metamorphosis 14(2): 20-29. https://doi.org/10.1177/0972622520150204

Tabachnick, B.G. and Fidell, L.S. (2001). Using Multivariate Statistics. 4th Edn., Allyn and Bacon, Boston, ISBN: 10: 0321056779, pp: 966

Yamaguchi, A. 2013. Influences of Social Capital on Health and Well-Being from Qualitative Approach. Global journal of health science 5(5): 153. https://www.ncbi.nlm.nih.gov/pmc/articles/PMC4776875/ 